\title{
The Improvement of Elementary School Teachers Through Web- Based Clinical Supervision
}

\author{
Rugaiyah Rugaiyah, Universitas Negeri Jakarta, Indonesia \\ Cecep Kustandi, Universitas Negeri Jakarta, Indonesia \\ Desi Rahmawati, Universitas Negeri Jakarta, Indonesia \\ Dini Nur Fadhillah, Universitas Sebelas Maret, Indonesia
}

\begin{abstract}
This study aimed to develop a valid draft clinical supervision web-based model for increasing the professionalism of elementary school teachers who have complete commitment, integrity, and competence in Jakarta, Indonesia. This study used qualitative research. Data was collected through observation and interview. The researcher worked together with three supervisors, five schools, two elementary school head chiefs, and three elementary school teachers. Clinical supervision consists of five phases following a research and development procedure, such as the initial preparation, observation, interpretation, post-observation meeting, and reverse meetings. The supervisor assessed explained clinical supervision web-based model was very effective and efficient considering teachers who had to be fostered in one target area, good communication between supervisors and teachers in the target area, because they could use the website and even upload videos teaching teachers in the classroom.
\end{abstract}

\section{KEYWORDS}

Elementary School Teacher, Web-Based Clinical Supervision

\section{INTRODUCTION}

In this technology era, the exceptional internet significance and potential as a mediator in data transferring combined with information technologies (Mkrttchian, V., Krevskiy, I., Bershadsky, A., Glotova, T., Gamidullaeva, L., \& Vasin, S., 2019). The development of this science supports the creation of new technologies related to education. Therefore, education itself should also take advantage of technology to assist in the implementation of learning. It is following the opinion of Fischl, Malinowsky, and Nilsson (2020), which states that digital technology has now begun to be used in educational institutions as a means to support learning, both as an information tool and a learning tool. A systems approach needs to be used to explain education because, in the current global era, the world of education has developed in such a way. Wu (2019) States that schools in the future must direct teachers and students to learn how to learn. Therefore, technological progress is a challenge for the quality of education. Besides that, education personnel professionalism is an important component in educational activities and the learning process(Walker, 2016). 
Global demands have changed the learning paradigm from the traditional learning paradigm to the modern learning paradigm(Popova-Nowak \& Cseh, 2015). The fact shows that the practice of learning applies more traditional learning strategies than new knowledge. The teacher center is still a learning model that teachers often use (Caughlan \& Jiang, 2014). Technology in education also encourages schools to improve educational management in teaching and learning activities in schools(Laurell, Sandström, Eriksson, \& Nykvist, 2020). According to educational management, it is a study and practice linked to educational organisations operations(Hartley, 2015). Therefore, this periodic arrangement of activities will be used as a benchmark in implementing operational activities manifested in educational management. According to Craig (2021), educational management is a form of collaboration between educational personnel to achieve academic goals. Likewise, school management changes the decision-making and management system for all stakeholders at the local level. Research of Benoliel (2020) explains that school management is an effort to empower schools and their environment to create an independent and effective school by optimizing the school roles and functions following the vision and mission set together. On the other hand, school management aims to empower schools by granting schools autonomy and encouraging schools to make participatory decision-making(Alanezi, 2019). One of them is improving education quality (Chen-Levi, Schechter, \& Buskila, 2020).

In the world of education, one of the skills learned is to improve the quality of education by giving authority, flexibility, and sharing responsibility to solve problems faced by the school concerned(Garira, 2020). So that teacher professionalism is essential to encourage better quality education. Besides that, school management promotes teacher and school principals' professionalism as educational leaders in schools (Deakin \& Kupchik, 2015). Advances in technology open up school management opportunities to carry out the learning process through interactive media( $\mathrm{Hu}$, Williams, Mason, \& Found, 2019). Thus, technology in education is only in the media position to achieve its learning objectives(Arar \& Nasra, 2020). Also, to improve education quality, the school management has become more accountable, transparent, egalitarian, and democratic with control from the community and government monitoring (Gallego-Arrufat, Gutiérrez-Santiuste, \& CampañaJiménez, 2017).

According to Bledsoe et al. (2018), supervision activities are carried out to improve and control all activities to be carried out optimally. On the other hand, the impact of supervision ensures that activities are effectively carried out by those responsible for carrying them out(Tang, 2019). Therefore, school management needs clinical supervision to focus on the school's daily activities and evaluate education management in schools(Tenuto, Gardiner, \& Yamamoto, 2016). Based on Mette and Riegel (2018), clinical supervision is a particular practice at the highest monitoring level because clinical supervisors prepare teachers and principals to increase their school commitment. For professional identity development, clinical supervision is needed to process trainee skills and knowledge in practical activities(Brown, Olivárez, \& DeKruyf, 2017). Therefore, supervision education activities are carried out to improve learning activities to support school goals' effectiveness. In general, the current supervision appears on the principal or supervisor's initiative, not from the teacher. Ideally, efforts to improve learning activities come from the teacher concerned, not from other parties. Initiatives to improve teacher abilities are very important to be developed(Gibbs et al., 2016). Because this is a seed that will soon be developed into awareness-based teacher capacity building activities, these activities are at the core of the clinical supervision concept(Garver \& Maloney, 2020).

According to Hoque et al. (2020), the purpose of clinical supervision is to help teachers develop and improve their professionalism through sharing planning, observation, and feedback between teacher and supervisor. Supervision activities are the main task and function of school principals and supervisors; supervision activities aim to improve learning activities; in this condition, the teacher looks passive(Damore \& Rieckhoff, 2019). Teachers are a component of human resources that must be nurtured and developed continuously to professionally carry out their functions(Dogan, Dawson, \& Ritzhaupt, 2020). It is hoped that the implementation of school supervisors' education, which is 
assumed to be a teacher guidance service, is expected to advance and develop teaching to do their job well(Hung, 2020). Research by Veloo, Komuji, and Khalid (2013) has shown the effect of clinical supervision on helping teachers to improve the learning process to be more effective and increasing student understanding.

In educational supervision activities, there are activities to measure teacher performance. Kotirde and Yunos (2015) explain that academic supervision can be interpreted as professional guidance for teachers. Professional advice is intended to develop teacher professionalism and improve student learning(Mather, McKay, \& Allen, 2015). So, it takes capabilities that are supported by technology and information. Therefore, the clinical supervision process requires innovation to improve the quality of clinical supervision(Aladağ \& Kemer, 2016). Several previous studies have shown that web-based clinical supervision is more widely used in the healthcare and aviation fields(X. V. Wu et al., 2020; Goo \& Seo, 2020). The lack of online-based clinical supervision on education is the purpose of this study to analyze the clinical supervision [online]. This study's research question is how to improve primary school teachers' quality through online clinical supervision.

\section{METHODS}

\section{Research Design}

Based on the research objectives related to elementary school teachers' improvement through online clinical supervision, the researcher used a qualitative approach(Creswell, 2017). This study intends to understand the phenomenon of what teachers, principals, and supervisors experience holistically and descriptions in the form of words and language related to online supervision. This study collaborated with four public schools and one private elementary school level in Jakarta, Indonesia. We collaborate with three teachers, four supervisors, and two school principals through purposive sampling with the following characteristics:

Table 1 shows that research subjects who are considered to meet the characteristics are supervisors, school principals, and teachers. To maintain the participant's code of ethics, the following is a list of names, positions, and duties of participants, as follows:

Based on table 2, the study participants amounted to 9 people consisting of four supervisors, two school principals, and three elementary school teachers. The number of women is four and men 5.

\section{Data Collection Technique}

Researchers collected data through interviews, observation, and documentation to obtain data related to the research objectives. In this study, interviews were conducted by gathering information, which was carried out by oral question and answer one-sidedly face to face and with predetermined directions and goals. Interviews were conducted in-depth and structured to research subjects with guidelines that have been made(Yin, 2011). The interview technique was used to reveal data about the informants' experiences in conducting clinical supervision through the website provided at https://supervisiklinis.

Table 1. Participant characteristics

\begin{tabular}{|c|l|}
\hline No. & \multicolumn{1}{|c|}{ Characteristic } \\
\hline 1. & Follow policies on school management \\
\hline 2. & Directly involved in the learning process and is responsible for school management \\
\hline 3. & Know the activities, supervise, and evaluate school management \\
\hline 4. & Have the ability to use the website \\
\hline
\end{tabular}


Table 2. Data of Participants

\begin{tabular}{|c|c|c|c|c|c|}
\hline No & Participant & Sex & Age & Position & Place of Duty \\
\hline 1 & SP-1 & P & 48 & Supervisor & Kecamatan Pulogadung \\
\hline 2 & SP-2 & L & 45 & Supervisor & Kecamatan Pulogadung \\
\hline 3 & SP-3 & P & 50 & Supervisor & Kecamatan Pulogadung \\
\hline 4 & SP-4 & L & 48 & Supervisor & Kecamatan Pulogadung \\
\hline 5 & CS-1 & P & 50 & Kepala Sekolah & SD IT At-Taubah \\
\hline 6 & CS-2 & L & 51 & Kepala Sekolah & SDN Pulogadung 09 \\
\hline 7 & T-1 & L & 38 & Guru & SDN Rawamangun 01 \\
\hline 8 & T-2 & L & 29 & Guru & SDN Pulogadung 05 \\
\hline 9 & T-3 & P & 40 & Guru & SDN Rawamangun 12 \\
\hline
\end{tabular}

com/. In this study, documentation was obtained from the archive of clinical supervision activities carried out by participants.

\section{Instrument}

Research instruments are tools or facilities used by researchers in collecting data and the results are better, in the sense that it is more accurate, complete, and systematic so that it is easier to process. Based on the data collection techniques used, the research instrument used an interview guide. The following is a grid table for the interview guide for supervision, school principals, and teachers.

The indicators of the success of clinical supervision are as follows:

Table 3. Supervision and Principal Interview Guide

\begin{tabular}{|c|l|l|c|}
\hline No & \multicolumn{1}{|c|}{ Indicator } & \multicolumn{1}{c|}{ Sub Indicator } & No. Item \\
\hline 1 & Planning & $\begin{array}{l}\text { - Make a clinical supervision plan } \\
\text { - Compiling a program }\end{array}$ & $1,2,3,4$ \\
\hline 2 & Implementation & $\begin{array}{l}\text { - Control in implementing the program } \\
\text { - Usability of the program } \\
\text { - Program quality } \\
\text { - Make program implementation decisions } \\
\text { - Running a supervision program }\end{array}$ & $5,6,7,8,9,10$ \\
\hline 3 & Observation & - Assessing the running of the program & 11,12 \\
\hline 4 & Evaluation & - Conduct evaluation and follow up on the program & $13,14,15$ \\
\hline
\end{tabular}

Source: (Sundler et al., 2019)

Table 4. Teacher interview guide

\begin{tabular}{|c|c|c|c|}
\hline No & Indikator & Sub Indikator & No. Item \\
\hline 1 & Implementation & $\begin{array}{c}\text { - Usability of the program } \\
\text { - Program quality }\end{array}$ & $1,2,3,4,5,6,7,8,9,10$ \\
\hline 2 & Evaluation & - Conduct evaluation and follow up on the program & $11,12,13$ \\
\hline
\end{tabular}

Source: (Sundler et al., 2019) 
Table 5. Indicators of the success of clinical supervision

\begin{tabular}{|l|l|}
\hline No & \multicolumn{1}{|c|}{ Indicator } \\
\hline 1 & increasing the ability of teachers to plan, implement, and evaluate the learning process \\
\hline 2 & $\begin{array}{l}\text { the quality of learning carried out by teachers are getting better, so it is expected that it will affect the quality of } \\
\text { the results learning achieved by students, }\end{array}$ \\
\hline 3 & $\begin{array}{l}\text { the establishment of collegial relationships between supervisors school with teachers in solving learning } \\
\text { problems and assignments profession }\end{array}$ \\
\hline
\end{tabular}

\section{Data Analysis Technique}

This research is a descriptive study, with more descriptive characteristics from interviews and documentation studies(Isaac \& Michael, 1971). The data that has been obtained will be analysed qualitatively and described in descriptive form. This study's data analysis techniques were data collection, data reduction, data display, and conclusion drawing. Furthermore, the data analysed and interpreted in the form of words to describe the facts in the field, meaning, or answer research questions then taken the gist.

\section{RESULTS AND DISCUSSION}

\section{The Application of Clinical Supervision}

Clinical supervision is professional assistance provided to teachers to improve their teaching competence which is focused on improving behavior/skills in specific teaching and learning processes. Therefore, the researcher aims to analyze the improvement of elementary school teacher through online clinical supervision. Teachers can understand how to control the class, motivate children, and use a scientific approach in the learning process. Before conducting the interview, the researcher introduced https://supervisiklinis.com/. Teachers, supervisors, and principals are directed to log in according to the direction of the researcher. On figure 1 is the homepage of the website https://supervisiklinis. $\mathrm{com} /$. Figure 2 is the process of logging in according to the role of the participants.

Based on Figure 2, the icon is red for the teacher, tosca for the supervisor, blue for the principal and yellow for the admin. After that, figures 3 and 4 appear to carry out the next process

Based on figure 4 . Informants are directed to fill in biodata, perform competences according to their roles. Here are the steps to use https://supervisiklinis.com/ for supervisors:

1. Fill in all the input on the "Lengkapi Biodata" page, upload the photo with a maximum size of $2 \mathrm{MB}$; after all the data is filled, click the save button.

2. Click "Kompetensi supervisi" and start to take a test.

3. Fill in all the input on the "observasi pembelajaran" download the teacher's learning program's design and syllabus.

4. Supervisors can download video recordings of teachers while teaching

5. Then, the supervisor chooses a supervision schedule and provides a report to the teacher via the https://supervisiklinis.com/ application

For teacher users, upload the design of the learning program and syllabus file with a maximum size of $2 \mathrm{MB}$ file. As for the learning video, the teacher uploaded it first on youtube and then pasted the video URL link uploaded to the Link column's learning record. After all entries have been completed the participant clicked the save button. There is a post-observation page that participant have to do their own assessment of the learning video that has been recorded and uploaded before in the Observation menu, the participant made an assessment by clicked the own assessment in the action column. 
Figure 1. The homepage of website https://supervisiklinis.com/

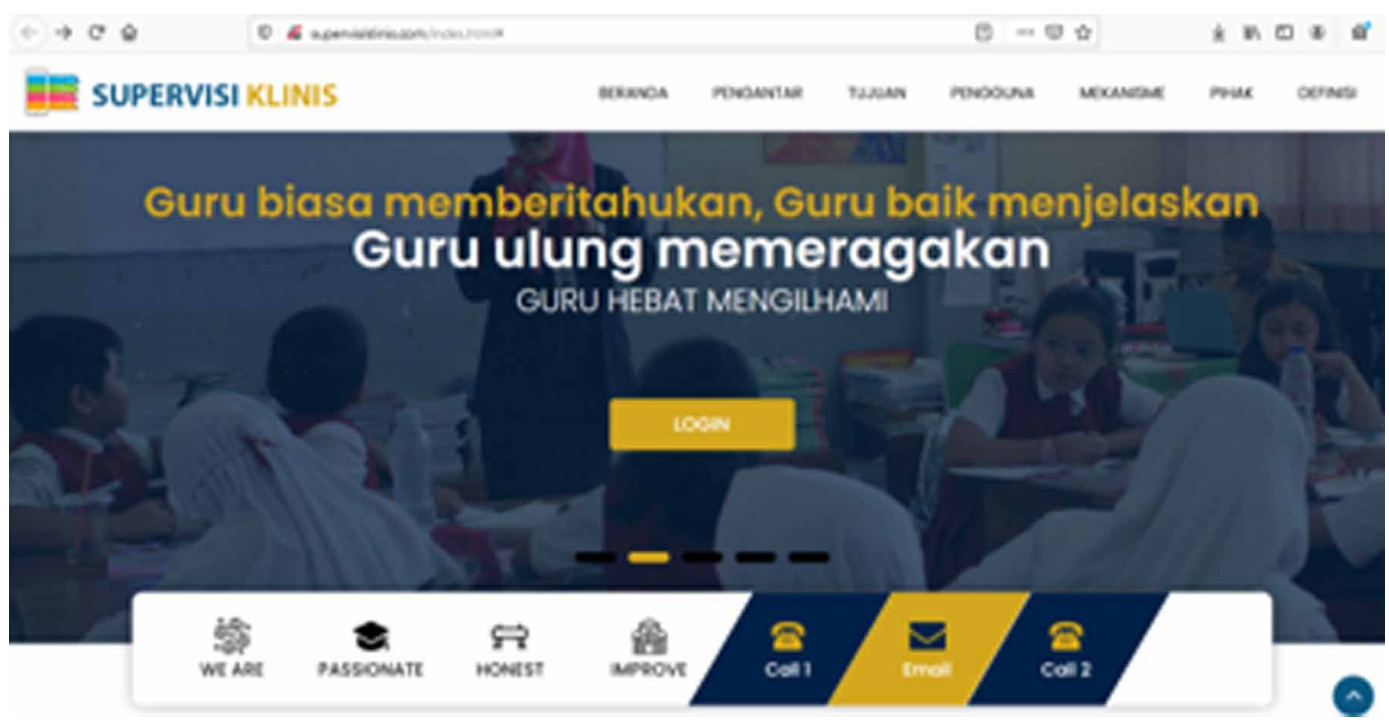

Figure 2. The process of login

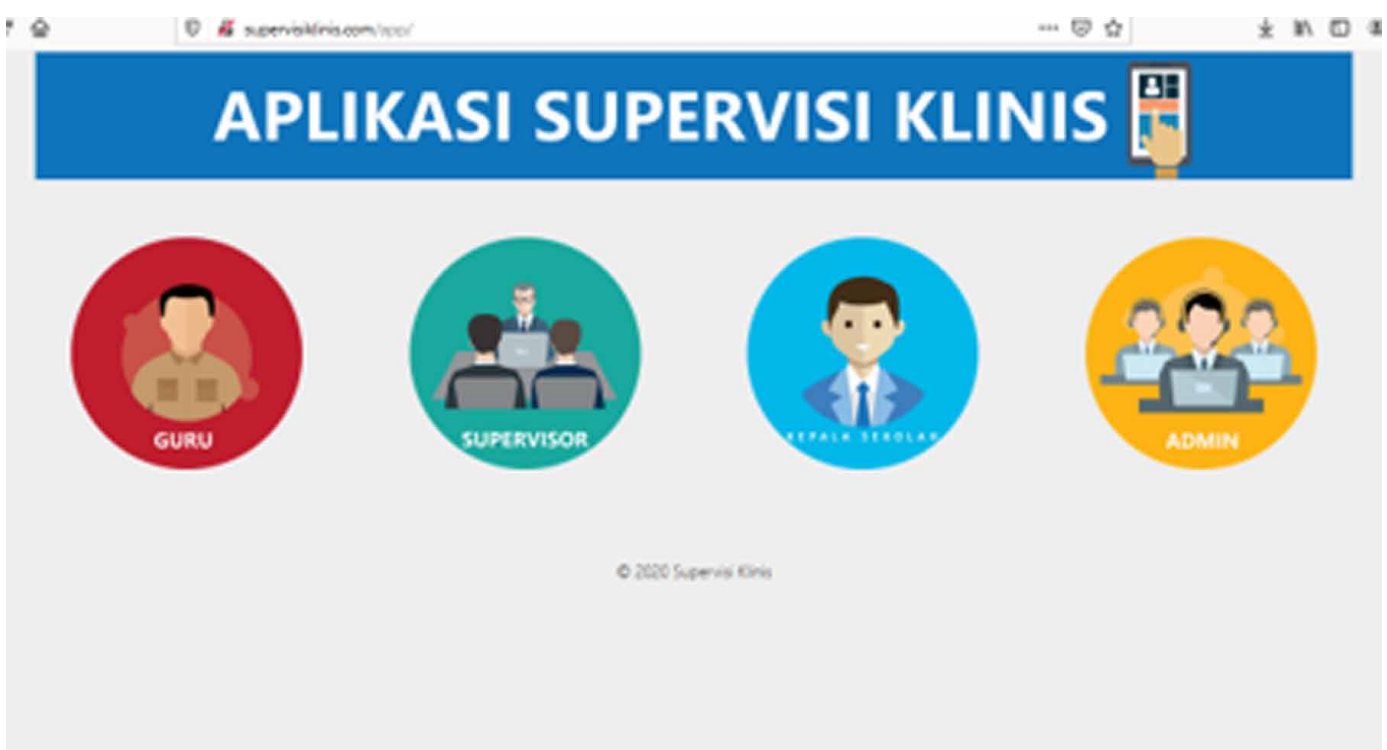

\section{The Improvement of Clinical Supervision [Online]}

Two assumptions underlie the practice of clinical supervision. First, learning is a very complex activity that requires careful observation and analysis through this observation and analysis; learning supervisors will efficiently develop the teacher's ability to manage the learning process. Second, teachers whose professionals want to be set prefer a collegial way rather than an authoritarian way. Therefore, after the researcher explained the application at https://supervisiklinis.com/, supervisors, school principals, and teachers were allowed to conduct clinical supervision for two full months. Interviews were conducted in two stages, namely when using the https://supervisiklinis.com/ 


\section{Supervisi Klinis}

\section{FORM LOGIN GURU}

Enter your username and password to iog on.

\section{Usemame}

Passmord

\section{IOOIN}

Figure 4. The dashboard of supervisor profile

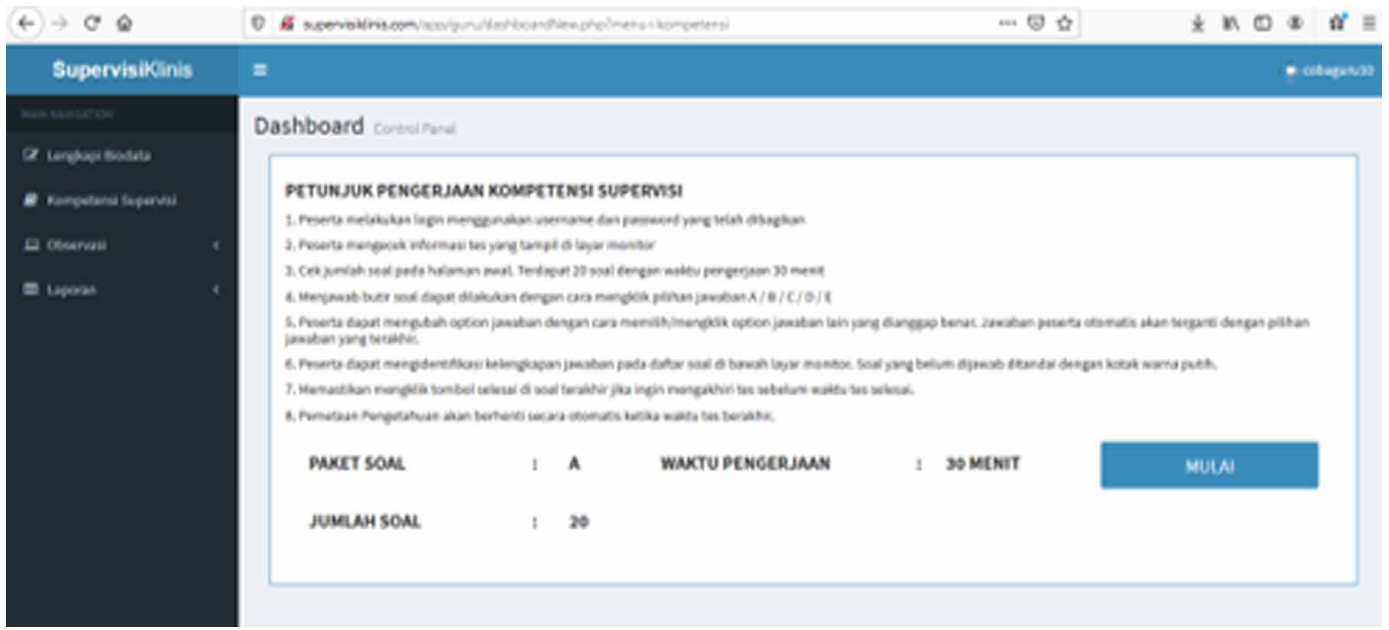

application and after using the application. Data (1) describes the planning, implementation, observation, and evaluation of the supervision and the principal. Data (2) describes the implementation and evaluation of the teacher. Interviews were conducted for 35 to 60 minutes in the first stage, and 60 to 90 minutes in the second stage.

(1) (1) The material contained on the clinical supervision web includes types of clinical supervision instruments. So, making supervision planning can be done effectively and efficiently (SP-1, 2020). The clinical supervision application helps me compile the program and includes learning 
supervision instruments (SP-2, 2020). This application is attractive and makes it easier for supervisors to make operational guidelines for implementing clinician supervision in elementary schools (SP-3, 2020). It helps me with the clinical supervision application because the tutorial is easy to understand. At the time of its use, it is very efficient (SP-4, 2020). As a principal, the presence of https://supervisiklinis.com/ makes it easier for me to control in implementing the program. In addition, the clinical supervision carried out by the research team provided training in the use of the application, and I can use a smartphone to access https://supervisiklinis.com/ so easily accessible with a limited connection (CS-2, 2020). Supervision is no longer limited by space and time to make observations. It can be done by viewing teacher learning videos uploaded into the clinical supervision application (SP-3, 2020). The clinical supervision application's quality can be said to be appropriate because it is following the supervisor's needs. Also, the suitability of the guidelines and assessments' contents makes it easier for supervisors and school principals to make implementation decisions (SP-2, 2020). The grammar, color suitability, and icon layout in the application are easy to read and attractive to supervisors (SP-4, 2020). In evaluating, the supervisor can write it down in the report column in the application. So, teachers can see notes that need to be improved (CS-1, 2020). After conducting an evaluation, the supervisor follows up by making a supervision schedule and seeing improvements in the teacher's teaching process (SP-2, 2020). This application is very effective when the supervisor performs the analysis by viewing the recorded video of learning (SP-1, 2020). The recordings' results can be seen clearly during the learning process as a whole, starting from the opening, core and closing activities (SP-1, 2020). In the core activity, recorded images show teacher activities in managing learning, how to interact with students, in using methods, student interactions during learning, and teacher performances, which display expressions during the learning process. In the closing activity, record the teacher and student activities' activities when ending the lesson in class. At the analysis stage: this model is developed into two analyzes. The teacher carried out the analysis; the teacher played back the video recording of his learning, then carried out a self-assessment related to his teaching activities. This assessment was carried out using the assessment format that has been provided on the web-clinical supervision. After the teacher conducts an independent assessment, the results are sent to the supervisor via web-clinical supervision. (CS-2, 2020).

(2) I feel helped by information technology in the form of a clinical.com supervision application. The observation and analysis stages can be strategic by uploading video recordings (T-1, 2020). In addition, the usefulness of this application is very useful in the presence of supervisors. They can be present at real-time and simultaneously see the learning process in a class by using video recordings (T-2, 2020). I only have to record teaching videos and upload them to the application. This activity is straightforward to do (T-3,2020). The teacher also conducts self-assessment related to the results of his teaching. After being analyzed by the supervisor the next stage, a face-to-face meeting is held and discussed to get a repair solution (T-2, 2020). It can make it easier for teachers and supervisors to carry out clinical supervision. As a teacher, I do not feel awkward learning and can do it anytime. It helps supervisors in setting the supervision schedule, considering that not only one teacher is supervised (T-3, 2020). Carry out clinical supervision independently; it is necessary to apply the following guidelines and clinical supervision instruments. So far, no application, guidelines or clinical supervision instruments have been developed for teachers and supervisors. The presence of https://supervisiklinis.com/ makes the implementation of supervision more effective $(\mathrm{T}-1,2020)$. The quality of the program https://supervisiklinis.com/ is excellent and easy to use. Besides, guidance and training are available before using the application (T-2, 2020). The visual appearance, presentation, and access to the clinical supervision web are very attractive. Supervisors can also analyze and provide input to me via email (T-1, 2020). As for preparing lesson plans, consultations with the supervisor, in this case, the principal or the fostered supervisor who are usually done submitting directly in hardcopy on this model, are done via email by first contacting the supervisor web-clinical supervision. 
Based on the data (1) it explains that the assessment is carried out through showing teacher teaching videos using the assessment format that has been provided. After evaluating each aspect, analyzing the learning outcomes, this assessment is collaborative in nature by utilising the nursing principle(Werler, 2015). And the application used is beneficial for supervisors in conducting the evaluation process. Meanwhile, data (2) shows that teachers are comfortable using clinical supervision applications. They no longer feel awkward in the learning process.

This research also in line with Esim et al. (2013) that the supervisor is not a leader but a colleague who can help the teacher improve teaching. Therefore, this study uses the assessment format that has been provided. At the face-to-face meeting stage between the supervisor and the teacher, a collegial meeting occurs to discuss the teacher's learning process while re-playing the video through webclinical supervision, if needed, at this stage, the supervisor explores more about what the teacher is experiencing—related to his teaching skills(Jia, Jung, \& Ottenbreit-Leftwich, 2018). The web-based supervision model utilizes technological devices; the teacher does not feel that their teaching skills are being assessed because the supervisor is not directly present in class. The two teachers also feel the need to evaluate their strengths and weaknesses, especially the shortcomings difficult to reveal. By viewing teaching video recordings, the teacher can see firsthand about their teaching skills, especially in terms of managing students in the classroom to learn in pleasant conditions and achieve high absorption(Lee, 2016)."As the principal, I feel this model is beneficial in providing professional guidance for teachers, by prioritizing self-assessment so that it does not appear that the principal shows a lack of teachers, but improvements are made based on facts and awareness or the desire of the teacher himself." (CS-2, 2020)

This supervision model is very suitable for building teachers who experience particular problems in learning. The initial study found that teachers and school principals' perceptions about clinical supervision were not optimally understood because the supervision carried out in schools was academic supervision as a routine managerial program to determine learning outcomes. At the same time, clinical supervision is focused on improving teaching skills in one aspect of skills such as explanation skills. The supervisor does not give much advice to the teacher but explores more about what the teacher thinks needs to be improved to improve his teaching competence(Meegan, Dunning, Belton, \& Woods, 2013)."In my opinion, as a teacher with the web-clinical supervision model, supervision can be done more naturally, in this condition the teacher does not feel that his teaching skills are being assessed because the supervisor is not present in the classroom. The teacher also feels the need to evaluate the strengths and weaknesses, especially the shortcomings that are difficult to reveal, because they feel they are good at teaching". (T-1, 2020)

By viewing video recordings teaching teachers on the web can see firsthand their teaching skills, especially in terms of managing students in the class to learn in pleasant conditions and achieve high absorption. This supervision model is very suitable for building teachers who experience special problems in learning. Likewise, the initial study found that teachers and school principals' perceptions about clinical supervision were not optimally understood because the supervision carried out in schools was academic supervision(Rugaiyah et al., 2019). School principals and supervisors' supervision activities were supervision as a routine managerial program to determine learning outcomes. In contrast, clinical supervision is focused on improving teaching skills in one aspect of skills such as explanation skills.

\section{DISCUSSION}

Referring to the theory put forward by Goktalay et al. (2014)explains the position of supervisors and the principal is an official who has the role in overseeing performance. Based on research finding, supervision is carried out to observe how the teacher carries out the implementation. In line with Bledsoe (2018) supervision can find out deficiencies or errors that need to be corrected and inputdeveloping competencies and skills in the preparation of instructional administration, both in selecting 
strategies, models, media and preparation. The supervision carried out by teachers aims to provide professional guidance to increase their professional competence(Asmarani, 2014). Through clinical supervision, teachers find it helpful to solve educational and learning problems they face(Veloo et al., 2013). Academic supervision focuses on the leadership function of the principal. In addition, this study found the use of technology and information is the essence of supervision to assess teacher performance in managing learning. On the other side, participants explained that clinical supervision online through https://supervisiklinis.com/ increasing competence focuses on improving teachers' skills and habits to achieve goals. So, to improve skills in using learning technology is effective for the supervisory process. The habit of arranging learning administration forms teachers to prepare for theoretical and scientific learning. This preparation can influence the practice of its implementation in the classroom.

Furthermore, these study results are in line with the opinion of Tubagus, Muslim, and Suriani (2020) explaining that in terms of implementation, it requires a conducive environment for the continuation of optimal interaction of teachers and students. This condition is shown by providing mutual input; this triggers enthusiasm to continue to develop. Following the researchers' findings regarding the ease of implementing clinical supervision online, this opens opportunities for teachers to get input about the learning process without feeling awkward. Providing space for teachers to get input from the principal and supervision makes them always self-evaluate their performance. Understanding of learning and curriculum will open and increase according to real conditions in the school environment. Likewise, Caena and Redecker (2019) professional competency development is a process that is interrelated and continuous, one of which is research as a follow-up to the supervision program. The teacher's ability to present learning refers to the teacher's ability and knowledge of the material to be delivered.

Teacher competency standards focus on the ability to apply knowledge and professional skills when teaching. The findings of this study show that teachers can design learning well according to the existing syllabus. The use of technology as a means of communication and self-development is one aspect of teacher professional competence. Teacher's knowledge of the development of student understanding is very important in this regard. The data findings in this study are following by Chawla and Joshi (2012) which identifies that the components in the perception of teacher competence are near related to the values and stages of child development. Teaching practices related to the use of media in practical learning help teachers find new perspectives on teaching experiences in class. In addition, academic supervision is also an effort to help teachers develop their abilities to achieve learning goals. Therefore, in this study, we used clinical supervision online to manage the learning process and help professional skills. Even so, academic supervision cannot be separated from teacher work assessments in managing learning. Academic supervision evaluation activities are carried out on the learning planning program and its implementation in the classroom is carried out with steps that have been systematically arranged.

\section{CONCLUSION}

Selection of the right media will definitely help teachers in delivering the material. The appearance of concrete media is good for low grade students, but for high-grade students, the use of abstract media will help students in their ability to analyze it. Academic supervision is a series of activities to help teachers develop their ability to manage the learning process for the achievement of learning objectives. Clinical supervision is part of teaching supervision. Teachers, supervisors and principals are expected to be able to open up to various technology products such as web-based clinical supervision, in order to improve teaching skills of teachers in the classroom. Efforts that can be made include exploring various facilities contained in web-based clinical supervision and various other sources of technology products. Future researchers are expected to continue conducting this research to develop web-based clinical supervision in a sustainable manner, in the aspect of dissemination and implementation on a large scale. 


\section{REFERENCES}

Aladağ, M., \& Kemer, G. (2016). Clinical supervision: An emerging counseling specialty in Turkey. The Clinical Supervisor, 35(2), 175-191. doi:10.1080/07325223.2016.1223775

Alanezi, A. (2019). Obstacles to applying electronic school management in Kuwait. Research in Education. Advance online publication. doi:10.1177/0034523719895042

Arar, K., \& Nasra, M. A. (2020). Linking school-based management and school effectiveness: The influence of self-based management, motivation and effectiveness in the Arab education system in Israel. Educational Management Administration \& Leadership, 48(1), 186-204. doi:10.1177/1741143218775428

Asmarani, N. (2014). Increased Teacher Professional Competence in Elementary Schools (Peningkatan Kompetensi Profesional Guru di Sekolah Dasar). Jurnal Administrasi Pendidikan, 2(1).

Benoliel, P. (2020). Principals' boundary activities and school violence: The mediating role of school management teams. Educational Management Administration \& Leadership, 48(2), 286-304. doi:10.1177/1741143218802592

Bledsoe, K. G., Logan-McKibben, S., McKibben, W. B., \& Cook, R. M. (2018). A Content Analysis of School Counseling Supervision. Professional School Counseling, 22(1). 10.1177/2156759X19838454

Brown, C. H., Olivárez, A., \& DeKruyf, L. (2017). The Impact of the School Counselor Supervision Model on the Self-Efficacy of School Counselor Site Supervisors. Professional School Counseling, 21(1). 10.5330/10962409-21.1.152

Caena, F., \& Redecker, C. (2019). Aligning teacher competence frameworks to 21st century challenges: The case for the European Digital Competence Framework for Educators (Digcompedu). European Journal of Education, 54(3), 1-14. doi:10.1111/ejed.12345

Caughlan, S., \& Jiang, H. (2014). Observation and Teacher Quality: Critical Analysis of Observational Instruments in Preservice Teacher Performance Assessment. Journal of Teacher Education, 65(5), 375-388. doi:10.1177/0022487114541546

Chawla, D., \& Joshi, H. (2012). Management education through e-learning in India: An empirical study. CampusWide Information Systems, 29(5), 380-393. doi:10.1108/10650741211275134

Chen-Levi, T., Schechter, C., \& Buskila, Y. (2020). Exploring Systems Thinking in Schools: Mental Models of School Management Teams. International Journal of Educational Reform. Advance online publication. doi: $10.1177 / 1056787920963650$

Craig, I. (2021). Whatever happened to educational management? The case for reinstatement. Management in Education, 35(1), 52-57. doi:10.1177/0892020620962813

Creswell, J. W. (2017). Research Design: Qualitative, Quantitative Mixed Methods Approaches. SAGE Publication.

Damore, S. J., \& Rieckhoff, B. S. (2019). School Leader Perceptions: Coaching Tool and Process. Journal of Research on Leadership Education, 1-24. 10.1177/1942775119868258

Deakin, J., \& Kupchik, A. (2015). Tough Choices: School Behaviour Management and Institutional Context. Youth Justice, 16(3), 280-298. doi:10.1177/1473225416665610

Dogan, N. A., Dawson, K., \& Ritzhaupt, A. D. (2020). Do School Levels Matter? How Elementary, Middle, and High School Teachers Differ in Their Perceptions and Use of Technology. Journal of Educational Technology Systems. doi:10.1177/0047239520961339

Esim, et.al. (2013). Clinical Supervision Model to Improve Supervisory Skills of Cooperating Teachers and University Supervisors during Teaching Practice. Hacettepe Üniversitesi Ĕ̆itim Fakültesi Dergisi (H. U. Journal of Education), 1, 191-203.

Fischl, C., Malinowsky, C., \& Nilsson, I. (2020). Measurement of older adults' performance in digital technologymediated occupations and management of digital technology. British Journal of Occupational Therapy. Advance online publication. doi:10.1177/0308022620937971 
Gallego-Arrufat, M. J., Gutiérrez-Santiuste, E., \& Campaña-Jiménez, R. L. (2017). School technology leadership in a Spanish secondary school: The TEI model. Improving Schools, 20(3), 247-263. doi:10.1177/1365480217732232

Garira, E. (2020). A Proposed Unified Conceptual Framework for Quality of Education in Schools. SAGE Open, 10(1). Advance online publication. doi:10.1177/2158244019899445

Garver, R., \& Maloney, T. (2020). Redefining Supervision: A Joint Inquiry Into Preparing SchoolBased Leaders to Supervise for Equity. Journal of Research on Leadership Education, 15(4), 330-355. doi: $10.1177 / 1942775119838301$

Gibbs, S., Atkinson, C., Woods, K., Bond, C., Hill, V., Howe, J., \& Morris, S. (2016). Supervision for school psychologists in training: Developing a framework from empirical findings. School Psychology International, 37(4), 410-431. doi:10.1177/0143034316653443

Goktalay, B. et al.. (2014). Clinical Supervision Model And Uludag Kdm. International Journal on New Trends in Education and Their Implications, 5(2), 1-11.

Goo, B., \& Seo, B. K. (2020). Strategies to revise the Korean Medicine Clinical Practice Guideline for lumbar herniated intervertebral disc-A web based approach. European Journal of Integrative Medicine, 37(July), 101169. doi:10.1016/j.eujim.2020.101169

Hartley, D. (2015). Economic crisis, technology and the management of education: The case of distributed leadership. Educational Management Administration \& Leadership, 44(2), 173-183. doi:10.1177/1741143214549974

Hoque, K. E., \& Kenayathulla, H. B., Subramaniam, M. V., \& Islam, R. (2020). Relationships Between Supervision and Teachers' Performance and Attitude in Secondary Schools in Malaysia. SAGE Open, 10(2). Advance online publication. doi:10.1177/2158244020925501

Hu, Q., Williams, S., Mason, R., \& Found, P. (2019). Knowledge management in consultancy-involved process improvement projects: Cases from Chinese SMEs. Production Planning and Control, 30(10-12), 866-880. do i:10.1080/09537287.2019.1582095

Hung, Y. H. (2020). Exploration of teachers' personal practical knowledge for teaching controversial public issues in elementary school classrooms. Journal of Social Studies Research, 44(3), 281-289. doi:10.1016/j. jssr.2020.04.001

Isaac, S., \& Michael, W. B. (1971). Handbook in Research and Evaluation. Robert R. Knapp.

Jia, X., Jung, J., \& Ottenbreit-Leftwich, A. (2018). Learning Technology Integration From a Service-Learning Project: Connecting Preservice Teachers to Real-World Problems. Journal of Experiential Education, 41(3), 261-276. doi:10.1177/1053825917738269

Kotirde, I. Y., \& Yunos, J. B. M. (2015). The Processes of Supervisions in Secondary Schools Educational System in Nigeria. Procedia - Social and Behavioral Sciences, 204(November), 259-264. 10.1016/j.sbspro.2015.08.149

Laurell, C., Sandström, C., Eriksson, K., \& Nykvist, R. (2020). Digitalization and the future of Management Learning: New technology as an enabler of historical, practice-oriented, and critical perspectives in management research and learning. Management Learning, 51(1), 89-108. doi:10.1177/1350507619872912

Lee, A. Y. L. (2016). Media education in the School 2.0 era: Teaching media literacy through laptop computers and iPads. Global Media and China, 1(4), 435-449. doi:10.1177/2059436416667129

Mather, C. A., McKay, A., \& Allen, P. (2015). Clinical supervisors' perspectives on delivering work integrated learning: A survey study. Nurse Education Today, 35(4), 625-631. doi:10.1016/j.nedt.2014.12.021 PMID:25618610

Meegan, S., Dunning, C., Belton, S., \& Woods, C. (2013). Teaching practice: University supervisors' experiences and perceptions of a cooperating physical education teacher education programme. European Physical Education Review, 19(2), 199-214. doi:10.1177/1356336X12473521

Mette, I. M., \& Riegel, L. (2018). Supervision, Systems Thinking, and the Impact of American School Reform Efforts on Instructional Leadership. Journal of Cases in Educational Leadership, 21(4), 34-51. doi: $10.1177 / 1555458918759696$ 
Mkrttchian, V., Krevskiy, I., Bershadsky, A., Glotova, T., Gamidullaeva, L., \& Vasin, S. (2019). Web-Based Learning and Development of University' s Electronic Informational Educational Environment. International Journal of Web-Based Learning and Teaching Technologies, 14(1), 32-53. doi:10.4018/IJWLTT.2019010103

Popova-Nowak, I. V., \& Cseh, M. (2015). The Meaning of Organizational Learning: A Meta-Paradigm Perspective. Human Resource Development Review, 14(3), 299-331. doi:10.1177/1534484315596856

Rugaiyah, R., Sulartinah, S., Kustandi, C., Rahmawati, D., Sujanto, B., Karnati, N., \& Hartati, S. (2019). Clinical Supervision Using Information Technology to Improve Teacher Quality. International Journal of Innovation. Creativity and Change, 10(9), 328-347.

Sundler, A. J., Blomberg, K., Bisholt, B., Eklund, A., Windahl, J., \& Larsson, M. (2019). Experiences of supervision during clinical education among specialised nursing students in Sweden: A cross-sectional study. Nurse Education Today, 79(March), 20-24. doi:10.1016/j.nedt.2019.05.009 PMID:31085423

Tang, A. (2019). The Impact of School Counseling Supervision on Practicing School Counselors' SelfEfficacy in Building a Comprehensive School Counseling Program. Professional School Counseling, 23(1). $10.1177 / 2156759$ X20947723

Tenuto, P. L., Gardiner, M. E., \& Yamamoto, J. K. (2016). Leaders on the Front Line-Managing Emotion for Ethical Decision Making. Journal of Cases in Educational Leadership, 19(3), 11-26. doi:10.1177/1555458916657123

Tubagus, M., Muslim, S., \& Suriani, S. (2020). Development of learning management system-based blended learning model using claroline in higher education. International Journal of Interactive Mobile Technologies, 14(6), 186-194. doi:10.3991/ijim.v14i06.13399

Veloo, A., Komuji, M. M. A., \& Khalid, R. (2013). The Effects of Clinical Supervision on the Teaching Performance of Secondary School Teachers. Procedia - Social and Behavioral Sciences, 93(2002), 35-39. 10.1016/j.sbspro.2013.09.148

Walker, Z. (2016). Special education teacher preparation in Singapore's dual education system. Teacher Education and Special Education, 39(3), 178-190. doi:10.1177/0888406415622251

Werler, T. (2015). Commodification of teacher professionalism. Policy Futures in Education, 14(1), 60-76. doi:10.1177/1478210315612646

Wu, R. (2019). Learning What to Learn Across the Life Span: From Objects to Real-World Skills. Current Directions in Psychological Science, 28(4), 392-397. doi:10.1177/0963721419847994

Wu, X. V., Chi, Y., Chan, Y. S., Wang, W., Ang, E. N. K., Zhao, S., Sehgal, V., Wee, F. C., Selvam, U. P., \& Devi, M. K. (2020). A web-based clinical pedagogy program to enhance registered nurse preceptors' teaching competencies - An innovative process of development and pilot program evaluation. Nurse Education Today, 84, 104215. doi:10.1016/j.nedt.2019.104215 PMID:31683138

Yin, R. K. (2011). Qualitative Research From Start to Finish. The Guilford Press.

Rugaiyah Ziyad is a professor of Educational Management Doctoral of Universitas Negeri Jakarta, Jakarta, Indonesia. She often wrote books, one of her book is The academic profession. She active publication on International and National Journal such as Jurnal Pendidikan Ekonomi dan Bisnis, Journal of Education Research in Administration and Managementand also International Journal of Research Studies in Education.

Cecep Kustandi is a doctoral candidate and also lecture of Educational Technology of Universitas Negeri Jakarta, Indonesia. He active at training and development program of Education Ministry in Indonesia. One of his famous book about "Manual Learning Media and Digital"and also often publication at Bagimu Negeri Jurnal Pengabdian Kepada Masyarakat, Atlantis Press and also IJISRT.

Desi Rahmawati is a lecture of Universitas Negeri Jakarta.

Dini Nur Fadhillah is master degree student of Pancasila and Civic Education, Universitas Sebelas Maret. 